\title{
Mapping Kesiapan Wajib Pajak terhadap Berakhirnya Penggunaan Peraturan Pemerintah No 23 Tahun 2018
}

\author{
Made Adi Guna Mertawan' ${ }^{1}$ \\ Fakultas Ekonomi dan Bisnis \\ Universitas Pendidikan Nasional, \\ Indonesia
}

\author{
Gede Sri Darma² \\ Fakultas Ekonomi dan Bisnis \\ Universitas Pendidikan Nasional, \\ Indonesia
}

Surel : adigunamertawan@gmail.com

ABSTRAK

Penelitian ini bertujuan untuk mengetahui sejauhmana kesiapan wajib pajak dalam peralihan penggunaan peraturan pemerintah No. 23 Tahun 2018 (PP 23/2018) menuju penggunaan tarif pasal 17 Undang-undang Pajak Penghasilan (UU PPh). Tujuan dikeluarkan PP 23/2018 adalah kebijakan pemerintah dalam menyederhanakan wajib pajak dalam melaksanakan administrasi perpajakan namun PP 23/2018 tidak selamanya dapat diterapkan melainkan terdapat batasan perioda penggunaan sebagai bentuk wajib pajak pembelajaran wajib pajak untuk dalam meningkatkan kepatuhan wajib pajak. Sampel penelitian ditentukan secara snowball dan purposive sampling yaitu wajib pajak yang berbentuk Persetoan Terbatas dengan data diperoleh dari observasi, wawancara dan dokumensi. Teknik analisis data yang digunakan adalah Teknik analisis kualitatif model Miles dan Hubberman. Hasil penelitian menunjukkan bahwa wajib pajak telah memahami dalam melaksanakan pembukuan namun pemahaman Pasal 17 UU PPh masih rendah, wajib pajak belum memperoleh informasi tentang batas waktu pengunaan PP 23/2018.

Kata Kunci: $\quad$ PP 23/2018; Pembukuan; Pasal 17 UU PPh.

\section{Mapping Taxpayer Readiness to End the Use of Government Regulation No. 23 of 2018}

\section{ABSTRACT}

This study aims to determine the extent of the readiness of taxpayers in the transition to the use of government regulation no. 23 of 2018 (PP 23/2018) towards the use of tariffs in Article 17 of the Income Tax Law (UU PPh). The purpose of issuing PP 23/2018 is the government's policy in simplifying taxpayers in carrying out tax administration, but PP 23/2018 can not always be applied but there is a limited period of use as a form of taxpayer learning taxpayers to improve taxpayer compliance. The research sample was determined by snowball and purposive sampling, namely taxpayers in the form of limited shares with data obtained from observations, interviews and documentation. The data analysis technique used is the Miles and Hubberman qualitative analysis technique. The results of the study indicate that taxpayers have understood in carrying out bookkeeping but understanding of Article 17 of the Income Tax Law is still low, taxpayers have not received information about the time limit for using PP 23/2018.

Keywords: $\quad$ PP 23/2018; Bookkeeping; Article 17 of the Income Tax Law.

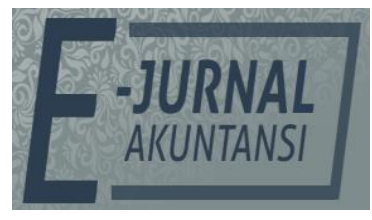

e-ISSN 2302-8556

Vol. 31 No. 9

Denpasar, September 2021 Hal. 2254-2264

DOI:

10.24843/EJA.2021.v31.i09.p08

PENGUTIPAN:

Mertawan, M.A.G.M., \&

Darma, G.S. (2021). Mapping Kesiapan Wajib Pajak terhadap Berakhirnya

Penggunaan Peraturan

Pemerintah No 23 Tahun

2018. E-Jurnal Akuntansi, 31(9), 2254-2264

RIWAYAT ARTIKEL: Artikel Masuk: 6 Mei 2021

Artikel Diterima: 8 September 2021

Artikel dapat diakses : https://ojs.unud.ac.id/index.php/Akuntansi/index 


\section{PENDAHULUAN}

Dalam menghitung pajak yang harus disetorkan kepada negara, wajib pajak badan harus melakukan pembukuan sesuai dengan ketentuan yang berlaku Umumnya tarif pajak penghasilan badan adalah 25 persen (dua puluh lima persen) dari penghasilan kena pajak. Penghasilan kena pajak dihitung dengan cara penghasilan dikurangi biaya-biaya yang yang boleh dibebankan sesuai dengan Undang-Undang Pajak Penghasilan. Penghasilan kena pajak juga bisa dihitung dengan menggunakan norma perhitungan yang ditentukan oleh pemerintah (UU PPh Pasal 14). Perhitungan pajak yang tidak sederhana ini membuat pemerintah melakukan terobosan penyederhanaan perhitungan pajak terutama bagi wajib pajak yang memiliki peredaran usaha dibawah 4,8 milyar rupiah dalam satu tahun (UMKM). Peraturan Pemerintah no 46 tahun 2013 (PP 46/2013) diterbitkan pada tanggal 12 Juni 2013 dengan tujuan untuk menyederhanakan perhitungan pajak yang harus disetor ke kas negara. PP 46/2013 mengatur tentang pajak atas penghasilan yang diterima atau diperoleh wajib pajak yang mempunyai peredaran bruto tertentu.

Budi (2013) mengatakan bahwa PP 46/2013 memberikan kemudahan dan kesederhanaan dalam pelaksanaan kewajiban perpajakan dimana penghitungan pajaknya didasarkan pada peredaran bruto (omset) sehingga mudah dalam menentukan pajak yang seharusnya dibayar, tanpa harus membuat pembukuan yang lengkap. Penerapan PP 46/2013 ini membawa kemudahan serta penyederhanaan dalam perhitungan perpajakan, sehingga Wajib Pajak semakin mudah dalam menghitung dan membayar pajak (Syafiqurrahman et al., 2017). Pemahaman wajib pajak pada PP 46/2013 secara signifikan mempengaruhi kepatuhan wajib pajak (Kartika \& Aji, 2016). PP 46/ 2013 juga memiliki peran penting terhadap kepatuhan wajib pajak karena peraturan ini dapat memberikan kemudahan dalam penghitungan, pembayaran, dan pelaporan pajak bagi wajib pajak (Kusbandiyah, et al., 2016) dan (Sutono \& Ardi, 2018). Penerapan PP 46/2013 juga berpengaruh dalam menambah tingkat kepatuhan wajib pajak dan penerimaan PPh final (Keziana, et al., 2013).

Kharisma, Anggraini, \& Arundhati (2014) menemukan hasil bahwa PP 46/2013 adalah kebijakan yang memberatkan pelaku usaha. Pajak sebesar 1 persen dari peredaran usaha dinilai tidak adil. Apabila mengalami kerugian wajib pajak harus tetap membayar pajak, dan hal ini memberatkan wajib pajak terutama UMKM (Susilo \& Sirajuddin, 2014). Pelaksanaannya PP 46/2013 juga menimbulkan penambahan administrasi pajak bagi Wajib Pajak yang menggunakannya (Arianty, 2017). Dampak atas penerapan PP 46/2013 dapat menguntungkan wajib pajak namun menurunkan penerimaan pajak (Prabantari \& Ardiyanto, 2017).

Sehingga untuk penyempurnaan PP 46/2013, pemerintah kemudian menerbitkan Peraturan Pemerintah No 23 tahun 2018 pada tanggal 8 Juni 2018 (PP 23/2018). Penerapan PP 23/2018 ini ternyata tidak serta-merta meningkatkan kepatuhan wajib pajak. Dibeberapa daerah di Indonesia, terutama untuk para wajib pajak yang baru, masih banyak yang belum mengetahui tentang peraturan ini (Hidayatulloh \& Fatma, 2019). Di daerah Manado misalnya, pertumbuhan wajib pajak tidak meningkat secara signifikan setelah PP 23/2018 diberlakukan (Suci, et al., 2019). Wajib pajak juga masih banyak yang belum melaksanakan 
kewajiban perpajakannya sesuai dengan PP 23/ 2018 (Mentari, 2019). Di Bandung, sebagian wajib pajak tidak memahami penerapan tarif PPh Final ini dan perubahannya. Hal ini disebabkan karena kurangnya respon wajib pajak terhadap aturan perpajakan akibat kurangnya sosialisasi (Kasir \& Hamdani, 2019). Sementara tingkat pengetahuan Wajib Pajak pengguna PPh Final di kota Malang terhadap PP 23/2018 tidak mempunyai pengaruh terhadap tingkat kepatuhan pajaknya (Harun, et al., 2019).

Konsep PP 23/2018 ini adalah bersifat meng-edukasi dan meningkatkan kepatuhan wajib pajak setelah jangka waktu tersebut terlampaui (Hutagaol, 2018). Pemahaman terhadap implemenasi PP 23/2018 dan pemahaman tentang perpajakan secara umum juga akan mempengaruhi kepatuhan wajib pajak (Christian, et al., 2019) dan (Listyaningsih, et al., 2019).

Beberapa titik penting dalam peraturan PP 23/2018 ini adalah turunnya tarif dari 1 persen menjadi 0,5 persen penyederhanaan dan perbaikan administrasi dalam hal pemungutan dan pemotongan serta yang paling penting adalah pembatasan jangka waktu penggunaan tarif pph final yakni mengatur adanya batasan waktu dalam penerapan PPh Final bagi wajib pajak tertentu antara tiga sampai tujuh tahun. Batasan waktu tersebut mengindikasikan bahwa penerapan PPh Final bersifat sementara sehingga wajib pajak diarahkan untuk mempersiapkan pembukuan yang lengkap dan sesuai standar yang berlaku dalam menghitung kewajiban perpajakannya. Batasan penggunaan PPh Final sesuai PP 23/2018 digambarkan sebagai berikut.

Tabel 1. Batas Waktu Penggunaan PP 23/2018

\begin{tabular}{ccc}
\hline Bentuk Hukum Wajib Pajak & $\begin{array}{c}\text { Jangka Waktu } \\
\text { Penggunaan PP 23/2018 }\end{array}$ & $\begin{array}{c}\text { Mulai Menggunakan } \\
\text { Pasal 17 UU PPh }\end{array}$ \\
\hline Perseroan Terbatas (PT) & 3 Tahun & 2021 \\
Koperasi/Persekutuan & 4 Tahun & 2022 \\
$\begin{array}{c}\text { Comanditer (CV), Firma } \\
\text { Orang Pribadi }\end{array}$ & 8 Tahun & 2026 \\
\hline
\end{tabular}

Sumber: Peraturan Pemerintah No 23, 2018

Setelah batasan waktu terlampaui, wajib pajak harus menggunakan kembali pasal 17 UU Pajak Penghasilan. Sehingga laporan keuanganpun harus dibuat sesuai dengan standar yang telah ditentukan. Bukan rahasia lagi dikalangan wajib pajak badan yang memenuhi ketentuan menggunakan PP23/2018, membuat laporan keuangan hanya sebagai syarat formal untuk melaporkan SPT Tahunannya. Hal ini karena laporan keuangan tidak mempunyai pengaruh dalam menentukan jumlah pajak yang dibayar saat penyampaian SPT Tahunan.

Saat ini laporan keuangan wajib pajak yang masuk katagori UMKM kualitasnya masih tergolong rendah (Suari \& Rasmini, 2018). Penelitian yang dilakukan Wahyuni (2017) menunjukkan bahwa UMKM masih mempunyai pemahaman yang kurang terhadap laporan keuangan. Mereka beranggapan bahwa pembukuan/akuntansi penting untuk dilakukan namun belum mempunyai sumber daya manusia yang mengerti dan memahami tentang pembukuan. Setelah jangka waktu penggunaan PP 23/2018 berakhir, wajib pajak ini harusnya benar-benar teliti dalam menyusun laporan keuangan karena berpengaruh terhadap perhitungan pajak yang harus dibayar. Wajib pajak yang 
berbentuk badan hukum perseroan terbatas harus sudah memakai skema umum (PPh pasal 17) mulai tahun 2021.

Hal ini ditegaskan lagi oleh pemerintah melalui Direktorat Jenderal Pajak melalui pengumuman no 10/PJ.09/2020 tanggal 07 September 2020 tentang Batas Waktu Penggunaan PPh Final Sesuai Peraturan Pemerintah Nomor 23 Tahun 2018 yang menegaskan bahwa terhitung mulai tahun pajak 2021 wajib pajak berbentuk perseroan terbatas tidak boleh menggunakan mekanisme perhitungan sesuai PP 23/2018 ini.

PP 23/2018 diterbitkan sebagai aturan yang disesuaikan dengan kondisi perekonomian terkini. Terdapat sejumlah ketentuan yang menjadi titik krusial dari peraturan ini yakni tarifnya menjadi 0,5 persen dan bersifat opsional (wajib pajak bisa memilih memakai pph final atau pasal $17 \mathrm{UU}$ PPh), penggunaan tarif pph final 0,5 persen mempunyai batas waktu, wajib pajak yang dikenai pph final mempunyai peredaran usaha di bawah 4,8 miliar rupiah pertahunnya, serta siapa saja yang bisa dan tidak bisa menggunakan tarif pph final ini (Indonesia, 2018).

Ariyanto \& Nuswantara (2020) menemukan bahwa pertumbuhan penerimaan dari pajak ini tidak terlepas dari adanya persepsi bahwa jenis pajak final ini meringankan dan mempermudah beban pajak. Hal ini yang dapat membangun kepatuhan Wajib Pajak. Senada dengan pemahaman terhadap implemenasi PP 23/2018, pemahaman tentang kewajiban perpajakan akan mempengaruhi kepatuhan wajib pajak (Listyaningsih et al., 2019).

Wardani \& Wati (2018) dalam penelitiannya mengatakan bahwa ternyata kebijakan penurunan tarif dan peningkatan kualitas layanan yang baik tidak menjadi jaminan untuk mendorong peningkatan sikap patuh Wajib Pajak. Wajib Pajak dengan pengetahuan perpajakan yang baik akan mendorong tingkat kepatuhan pajak kearah yang lebih baik.

Sementara itu pasal 31E Undang-undang No.36 (2008) menyatakan bahwa Wajib Pajak badan dalam negeri yang mempunyai peredaran bruto sampai dengan Rp 50 miliar rupiah mendapat fasilitas berupa pengurangan tarif sebesar 50 persen. Tarif PPh Badan yang berlaku saat ini adalah 25 persen, sehingga Wajib Pajak badan dalam negeri yang memenuhi syarat tersebut (UMKM yang peredaran brutonya dibawah 4,8 Milyar pertahun), tarifnya menjadi efektif yakni 12,5 persen untuk yang peredaran usaha sampai dengan Rp.4,8 miliar rupiah. Perhitungan pajak penghasilannya dihitung berdasarkan penghasilan kena pajak yang dihitung laba-rugi akuntansi (pembukuan) setelah dilakukan koreksi fiskal (Endrianto, 2015). Penelitian oleh Harwida, \& Kurniawan (2011) menemukan fenomena bahwa UMKM cukup paham tentang substansi pajak dan bagaimana pajak memberikan pengaruh/persepsi kearah kecenderungan bahwa pajak itu merepotkan karena terdapat banyak hal yang harus dikerjakan.

Hermanto \& Rasmini (2015) menjelaskan tentang bagaimana menghitung penghasilan kena pajak Penghitungan besarnya penghasilan neto bagi wajib pajak dalam negeri dapat dilakukan dengan dua cara, yaitu menggunakan pembukuan dan menggunakan norma penghitungan penghasilan neto.

Sejauhmana kesiapan wajib pajak yang berbentuk Perseroan Terbatas dalam menggunakan pasal $17 \mathrm{UU}$ PPh untuk menjalankan kewajiban perpajakannya pada saat jangka waktu penggunaan PPh Final (PP 23/2018) berakhir menjadi hal yang menarik untuk diketahui. Secara praktis hal ini bisa menjadi peringatan dini 
bagi para wajib pajak badan terutama berbadan hukum perseroan terbatas (PT), untuk mempersiapkan pembukuan sesuai dengan standar yang sudah ditetapkan. Tujuan dari penelitian ini adalah untuk mengetahui kesiapan wajib pajak menggunakan pasal 17 UU PPh dalam melaksanakan kewajiban perpajakannya.

\section{METODE PENELITIAN}

Penelitian ini merupakan sebuah penelitian dengan metode kualitatif dengan pendekatan fenomenologi dan lokasi penelitian ditentukan secara sengaja (purposive), yang dilakukan di Kantor Pelayanan Pajak Denpasar Barat yang beralamat di Jalan Raya Puputan No 13 Denpasar. Digunakannya metode penelitian kualitatif karena peneliti ingin melakukan pengamatan dan mendapatkan informasi langsung dari sumber data melalui wawancara mendalam secara langsung dengan wajib pajak, observasi dan dokumentasi data yang telah dikumpulkan. Menanyakan kepada para informan melalui wawancara adalah satu-satunya cara untuk mengetahui pengalaman/persepsi tentang pemahaman pajak (Raco, 2018). Penentuan lokasi dilakukan karena wilayah kerja pengawasan Kantor Pajak Pelayanan Denpasar Barat yang meliputi Kecamatan Denpasar Barat dan Denpasar Utara merupakan pusat bisnis dan perdagangan di Bali. Langkah yang paling utama dalam penelitian adalah teknik pengumpulan data, karena tujuan utama dari penelitian adalah mendapatkan data. Menurut Sugiyono (2016), teknik pengumpulan data dapat dilakukan dengan observasi, wawancara, dan dokumentasi.

Penentuan informan dilakukan dengan menggunakan metode purposive sampling dan snowball. Jumlah informan dalam penelitian ini adalah 6 (enam) orang. Alasan digunakannya teknik ini adalah pada situasi tertentu, jumlah subjek penelitian yang terlibat menjadi bertambah karena subjek atau informan penelitian yang telah ditentukan sebelumnya kurang memberikan informasi yang mendalam atau pada situasi-situasi tertentu tidak memungkinkan peneliti untuk mendapatkan akses pada sumber, lokasi atau subjek yang hendak diteliti. Secara lebih detail penentuan informan dilakukan dengan kriteria $5 W 1 H$ (What : Informan merupakan Wajib Pajak berbentuk PT yang terdaftar di KPP Pratama Denpasar Barat, Who: Pegawai Administrasi/Accounting/pengurus/direktur yang bekerja di Perusahaan (PT), Why: Wajib Pajak berbentuk PT yang paling pertama terkena efek dari berakhirnya penggunaan mekasnisme PPh Final ini (3 tahun sejak PP23/2018 diterbitkan), When: Penelitian akan dilakukan selama 1 sd 2 bulan untuk wawancara langsung. Rentang waktu disediakan agar informan sesuai dengan kriteria dapat ditemui, Where: Tempat Wawancara bersifat fleksibel dengan mempertimbangan waktu, biaya dan kenyamanan, How: Wajib Pajak yang akan menjadi informan ditentukan dengan menambah beberapa kreteria seperti NPWP wajib pajak adalah aktif, melakukan pembayaran pajak secara kontinyu yang menandakan bisnis wajib pajak stabil, melaporkan SPT masa dan Tahunan dengan tertib, dan peredaran usaha wajib pajak dibawah 4,8 Miliar ditahun 2019)

Sementara metode snowball digunakan sebagai acuan bahwa ketika peneliti mendapatkan hasil wawancara yang serupa dari informan yang diwawancarai, maka peneliti menentukan bahwa informan sudah cukup mewakili populasi. Informan yang diwawancarai yang merupakan perwakilan dari wajib pajak 
(berbadan hukum PT) baik pemilik langsung maupun pegawai yang diberi kepercayaan oleh pemilik untuk menangani pembukuan dan perpajakan.

Pengumpulan data dilakukan dengan wawancara mendalam kepada informan yang telah ditentukan. Setelah data diperoleh baik melalui wawancara ataupun dari dokumen profil wajib pajak, dokumen tersebut dipelajari, dirangkum dan ditelaah serta dianalisa. Analisa data yang diperoleh mengikuti model Miles dan Huberman (Berg \& Lune, 2017) yakni menggunakan tiga jenis analisa data yaitu memilih dan menyederhanakan data, menjadikan data yang bersifat umum yang diperoleh menjadi catatan lapangan (reduksi data). dilanjutkan dengan penyajian data yakni merangkum data untuk memudahkan untuk dapat menarik kesimpulan dari penelitan. Penarikan kesimpulan dan verifikasi pengumpulan data yang diperoleh dilapangan.

\section{HASIL DAN PEMBAHASAN}

Untuk mengetahui kesiapan wajib pajak menggunakan pasal 17 UU PPh, wawancara mendalam dilakukan kepada informan. Berdasarkan hasil wawancara, pada informan ke-6, peneliti mendapatkan hasil wawancara yang serupa dengan informan sebelumnya sehingga informan yang diwawancarai berhenti pada informan ke-6.

Semenjak Wajib Pajak UMKM (Peredaran usaha dibawah 4,8 Miliar) menggunakan PPh Final, hal ini sangat memudahkan dalam melakukan perhitungan perpajakan. Wajib Pajak hanya perlu menghitung peredaran usaha tanpa memperhatikan kewajaran laporan keuangan. Laporan Keuangan hanya menjadi pelengkap untuk pelaporan spt tahunan.

"Wah, saya tidak fokus dengan laporan rugi laba, karena tidak dipakai di SPT tahunan, hanya sebagai syarat untuk lapor saja, tidak berpengaruh terhadap pajak yang dibayar, jadi benar atau tidak juga tidak berpengaruh" Ibu Kadek Direktur PT ASI).

Dimulai dari PP 46/2013 dengan tarif 1(satu) persen, PT GDB yang diwakili oleh pegawai administrasi mengatakan bahwa perhitungan pajak dengan menggunakan PPh Final dalam menghitung pajak menjadi sangat mudah.

" Pajak 0,5 persen ini sangat mudah, tinggal tahu penjualannya berapa, lalu dikalikan dengan tarif, tidak perlu lagi mengurangkan dengan biaya, dan saya tidak tahu mana biaya yang boleh dipakai dan yang tidak" (ibu Sinta - Admin PT GDB).

"Gampanglah kalau pajak sekarang ini, tinggal rekap saja penjualan harian, akhir bulan dikumpulkan akan diperoleh peredaran usahanya, besoknya langsung bayar pajaknya di ATM" (Bapak Made - Direktur PT CUK).

Namun dalam pelaksanaannya wajib pajak juga mengeluhkan penerapan PPh Final ini. Karena perhitungannya dari peredaran usaha, maka wajib pajak akan tetap membayar pajak walaupun perusanaan dalam keadaan rugi.

"Pajak 0,5 persen ini menurut saya tidak adil karena margin perusahaan saya kecil, belum lagi saya harus bayar karyawan, uang ini itu lah yang kalau dihitung-hitung, bisa jadi perusahaan saya rugi, tapi saya masih tetap bayar pajak" (Bapak Wayan S - Direktur PT WULK).

"Masa tidak ada kebijakan pajak? kadang saat bulan-bulan tertentu saya rugi karena pengeluaran lebih besar, saya masih harus tetap bayar pajak, 
akhirnya saya perkecil saja peredaran usahanya agar bisa nutup" (Bapak Made - Direktur PT CUK).

Penerapan PPh Final ini memang tidak mengenal rugi ataupun untung. Wajib pajak harus tetap membayar pajak selama ada peredaran usaha. Peredaran usaha dan biaya yang besar diikuti keutungan yang tipis, wajib pajak harus membayar pajak yang relatif besar.

Sementara temuan persepsi informan terhadap Pembukuan dan Laporan Keuangan serupa bahwa semua informan memahami akan kewajiban membuat laporan keuangan. Undang-undang no 40 tahun 2007 tentang Perseroan Terbatas mewajibkan badan hukum berbentuk PT untuk membuat laporan keuangan yang disusun berdasarkan standar akuntansi keuangan. Karenanya menurut Bapak G, selaku pemilik dari PT. GDB merekrut seorang akuntan yang bisa dipercayai untuk pembuatan laporan keuangan. Hal ini mengingat bahwa laporan keuangan yang baik menggambarkan usaha yang dijalankan sehat atau tidak. Ibu Sinta selaku admin/accounting dari PT GDB tidak terlalu sulit dalam membuat laporan keuangan mengingat latar belakang pendidikannya dari Akuntansi. Sejalan dengan itu, staff admin dari PT GM - Ibu L mengatakan bahwa dalam pembuatan laporan keuangan, pihaknya menggunakan system aplikasi sehingga laporan keuangan tersusun secara otomatis. Ibu L juga bertanggung jawab terhadap proses selama pembuatan laporan keuangan. Informan juga mengatakan bahwa mengerahui namun tidak terlalu memahami tentang laporan keuangan.

"Saya hanya tahu pembukuan sedikit, dan saya tidak mau pusing memikirkannya, saya fokus di penjualan saja. Data cashflow, penjualan dan biaya saya ada, tapi saya tidak bisa membuat laporan keuangan, jadi saya memakai jasa konsultan untuk pembuatan laporan keuangan" (Bapak Wayan S - Direktur PT WULK).

"Kami normal-normal saja dalam membuat pembukuan, tidak ada yang dibuat-buat untuk mengecilkan laporan keuangan. Saya dibantu admin mengerjakan laporan keuangan, saya tahulah mengenai laporan keuangan karena basic saya ekonomi" (Ibu Kadek A - Direktur PT ASJ).

"Saya tidak terlalu tahu pembukuan dsb, saya ada yang bantu dalam membuat laporan keuangan, saya hanya serahin data, benar atau tidak saya kurang tahu"(Bapak Made S - Direktur PT. CUK).

"Kalau untuk pembukuan, saya tahu sedikit, bisa membaca tentang laba/rugi, sebagai pemilik saya harus tahu usaha saya untung atau rugi" (Bapak Made D - Direktur PT CDA).

6 (enam) informan yang diwawancarai semuanya menyatakan mengetahui akan kewajiban melaksanakan pembukuan dan laporan keuangan. Walaupun secara teknis ada beberapa yang tidak mengetahui prosesnya, namum bisa menggunakan dan membaca laporan keuangan untuk mengetahui keadaan perusahaan. Secara umum, informan juga melakukan pencatatan setiap transaksi yang berhubungan dengan kegiatan usaha sebagai bagian dari proses pembuatan laporan keuangan.

Mulai tahun 2021 wajib pajak berbentuk PT kembali menggunakan PPh Pasal 17 sebagai dasar dalam menghitung pajak yang harus dibayar. Hal tersebut ditegaskan oleh Direktorat Jenderal Pajak dalam pengumumannya no PENG - 
10PJ.092020 tanggal 07 September 2020. Sebagai pemberitahuan ke wajib pajak, Kantor Pelayanan Pajak Denpasar Barat menerbitkan surat S159/WPJ.17/KP.01/2021 tanggal 15 Januari 2021 yang isinya adalah pemberitahuan batas waktu penerapan pajak penghasilan final berdasarkan PP 23/2018 bagi wajib pajak badan. Surat ini kemudian dijadikan sebagai salah satu dasar dalam wawancara dengan informan.

Informasi yang disampaikan oleh informan, semuanya menyatakan tidak mengetahui tentang batas waktu penggunaan pph final ini. Seperti yang diungkapkan oleh Ibu Sinta selaku admin PT GDB.

"Saya tidak tahu kalo tahun ini sudah tidak boleh memakai PPh Final, dan saya tidak mengerti pph pasal 17 itu apa, tetapi kalau nanti semuanya berawal dari proses pembukuan dan laporan keuangan, tentu saja kami siap karena khan kami sudah membuat laporan keuangan sesuai standar keuangan" (Ibu Sinta - Admin PT GDB)

Hal yang sama juga diungkapkan Ibu Kadek A, Direktur PT ASJ yang mangatakan bahwa pihaknya tidak mengetahui cara perhitungan pph pasal 17 dan memerlukan penjelasan dari petugas pajak. PT ASJ juga menyatakan kesiapannya menggunakan mekanisme pph pasal 17 karena pembukuan sudah dilaksanakan sesuai dengan standar yang berlaku dan hanya memerlukan penjelasan teknis dari petugas pajak.

"Pajak apa itu? saya tidak tahu, saya tahunya cuma yang setor setiap bulan, tarifnya 0,5 persen. Saya juga tidak tahu harus memakai itu untuk tahun ini". (Ibu Lindiana -Admin/ ACC PT GM).

Demikian potongan pernyataan dari salah satu informan yang menyatakan belum mengetahui perihal penggunaan pasal 17 dalam menghitung pajak yang harus dibayar. Namun karena system pembukuannya sudah baik, maka hal tersebut tidaklah menjadi hal yang sulit untuk dilakukan.

Informan yang mengerti tentang pembukuan dan mengerjakan prosesnya sendiri masih belum tahu info tentang batas waktu ini, sementara untuk informan yang hanya melakukan melakukan pencatatan transaksi dan menggunakan jasa pihak luar untuk proses laporan keuangan juga menyatakan hal yang sama.

"Saya tidak tahu apa itu pph pasal 17, kl dulu sebelum pake yang 1 persen dan 0,5 persen, saya pernah denger kalau pajaknya dibyar pada awal tahun saat laporan tahunan, mngkn itu yang dimaksud" (Wayan S - Direktur PT WULK).

"Wah, apalagi ini, saya bener-bener ngk tau, saya dibantu untuk konsultan untuk perpajakannya, saya fokus ke bagaimana untuk mencari proyek" (Bapak Made D - Direktur PT CDA).

"Saya baru denger pajak yang pasal 17 ini, kalau ngitungnya dari laba, bagus itu, jadi lebih adil" (Bapak Made S - Direktur PT CUK).

\section{SIMPULAN}

Wajib Pajak yang berbentuk Perseroan Terbatas (PT) sudah memahami kewajibannya dalam membuat laporan keuangan sesuai dengan standar yang telah ditentukan meskipun beberapa wajib pajak masih menggunakan jasa konsultan dalam menyusunnya. Sehingga bisa disimpulkan bahwa menggunakan 
Pasal 17 UU PPh tidaklah terlalu sulit untuk dilakukan. Kesiapan Wajib Pajak untuk menggunakan pasal 17 UU PPh dalam melaksanakan kewajiban perpajakannya adalah sudah siap.

Dalam hal penyampaian informasi ini dari pihak otoritas pajak kepada wajib pajak masih sangat minim. Tercermin dari wajib pajak yang tidak tahu akan berakhirnya penggunaan PP 23/2018 bagi Perseroan Terbatas. Otoritas pajak dalam hal ini Direktorat Jenderal Pajak (DJP) sudah melakukan langkah-langkah dalam mengantisipasi hal ini antara lain dengan mengeluarkan surat dan pengumuman. Namun dilapangan, informasi tersebut belum sampai kepada wajib pajak. DJP sebaiknya terus meningkatkan kegiatan sosialisasi tentang batas waktu penggunaan PP 23/2018 terutama kepada wajib pajak badan selain PT yang akan mulai menggunakan mekanisme Pasal 17 UU PPh mulai tahun 2022.

Dengan keterbatasan pada penelitian ini diharapkan penelitian berikutnya perlu menggali tentang kesiapan wajib pajak badan selain berbentuk PT (CV, Koperasi, Yayasan, Firma dan sebagainya) dalam menggunakan mekanisme Pasal 17 UU PPh. Metodologi yang digunakan juga bisa lebih variatif dengan kombinasi kualitatif dan kuantitatif.

\section{REFERENSI}

Arianty, F. (2017). Tinjauan Atas Asas Keadilan \& Kemudahan Administrasi Pajak Dalam Pengenaan Pajak Penghasilan Final 1\% Terhadap Wajib Pajak Umkm. Jurnal Vokasi Indonesia, 5(1). https://doi.org/10.7454/jvi.v5i1.66

Ariyanto, D., \& Nuswatara, D. A. (2020). Pengaruh Persepsi Tarif Pajak Terhadap Kepatuhan Wajib Pajak UMKM. 8(3).

Berg, B. L., \& Lune, H. (2017). Qualitative Research Methods for the Social Sciences. (8th ed.). California State University, Long Beach Howard Lune, Hunter College: Pearson.

Budi, C. (2013). Jutaan UMKM Pahlawan Pajak: Urus Pajak Itu Sangat Mudah (Indonesian Edition) (Indonesia). Retrieved from https://news.ddtc.co.id/memahami-pajak-pajak-untuk-umkm7635?page_y $=320$

Christian, Y. A., Nangoi, G. B., \& Budiarso, N. S. (2019). Implikasi Pengenaan Pajak Penghasilan Final Terhadap Penghitungan Pajak Penghasilan Badan Pada Pt. Empat Tujuh Abadi Jaya. Going Concern : Jurnal Riset Akuntansi, 14(1), 10-17. https://doi.org/10.32400/gc.14.1.22243.2019

DJP. (2020). Pengumuman Tentang Batas Waktu Penerapan Pajak Penghasilan Final Berdasarkan Peraturan Pemerintah Nomor 23 Tahun 2018 Bagi Wajib Pajak Badan.

Endrianto, W. (2015). Prinsip keadilan dalam pajak atas umkm. BINUS Business Review, 6(9), 298-308.

Harun, I., Diana, N., \& Mawardi, C. M. (2019). Analisis Penerapan Peraturan Pemerintah No.23 Tahun 2018 Bagi Umkm Di Kota Malang. E-Jra, 08(01), 113.

Hermanto, D. H. B., \& Rasmini, M. (2015). Konsep Dasar Pajak Penghasilan Wajib Pajak Badan dan BUT. 1-37.

Hidayatulloh, A., \& Fatma, F. D. (2019). Sosialisasi Peran Umkm Dan Peraturan Pemerintah Sadar Pajak. Jurnal Pengabdian Untuk Mu NegeRI, 3(1), 29-32.

Hutagaol, J. L. (Ketua I. K. (2018). PP 23/2018 Bentuk Dukungan DJP untuk 
UMKM. Retrieved April 7, 2020, from https://news.ddtc.co.id website: https:/ / news.ddtc.co.id/pp-23-2018-bentuk-dukungan-djp-untuk-umkm13418

Indonesia. Undang Undang No 36 Tahun 2008 tentang Pajak Penghasilan. , Jakarta: Sekertariat Negara § (2008).

Indonesia. Peraturan Pemerintah No 23 Tahun 2018 Tentang Pajak Penghasilan Atas Penghasilan Dari Usaha Yang Diterima Atau Diperoleh Wajib Pajak Yang Memiliki Peredaran Bruto Tertentu. , Peraturan Pemerintah No. 23 § (2018).

Kartika, Y. T., \& Aji, A. W. (2016). Analisis Pengaruh Pemahaman Ketentuan Dan Presepsi Wajib Pajak Tentang Peraturan Pemerintah Nomer 46 Tahun 2013 Terhadap Kepatuhan Dalam Melaksanakan Ketentuan Pada Wajib Pajak Pelaku Usaha Mikro Kecil Dan Menengah Di Kota Yogyakarta. Jurnal Akuntansi, 3(2), 61. https:// doi.org/10.24964/ja.v3i2.51

Kasir, K., \& Hamdani, D. (2019). Persepsi Pelaku Usaha Umkm Tentang Tarif Final 1\% Menjadi Tarif Final 0,5\% Di Kota Bandung. Sosiohumaniora, 21(3), 269-278. https://doi.org/10.24198/sosiohumaniora.v21i3.23455

Keziana, Anwar, M., \& Wirshandono Y, D. (2013). Tingkat Kepatuhan Wajib Pajak Dan Penerimaan Pph (Studi Di Kantor Pelayanan Pajak Pratama Kepanjen ). (46), $1-14$.

Kharisma, R., Anggraini, R., \& Arundhati, G. B. (2014). Pengaruh Pelaksanaan Peraturan Pemerintah Republik Indonesia Nomor 46 Tahun 2013 Terhadap Kelangsungan Usaha Mikro Kecil Dan Menengah ( Umkm ). Artikel Ilmiah Hasil Penelitian Mahasiswa, 1-9.

Kusbandiyah, A., Mudjiyanti, R., \& Wibowo, H. (2016). Pengaruh Persepsi Pp Nomor 46 Tahun 2013 Terhadap Kepatuhan Sukarela Wajib Pajak Yang Memiliki Peredaran Bruto Tertentu Pada Kantor Pelayanan Pajak Pratama Purwokerto. Journal of Chemical Information and Modeling, 53(9), 1689-1699. https:// doi.org/10.1017/CBO9781107415324.004

Listyaningsih, D., Nurlaela, S., \& Dewi, R. R. (2019). Implementasi PP No 23 Tahun 2018, Pemahaman Perpajakan, Dan Sanksi Perpajakan Terhadap Kepatuhan Wajib Pajak Usaha Mikro, Kecil, dan Menengah Di Kota Surakarta. Universitas Islam Batik Surakarta, 03(01), 2016-2019.

Mentari, T. C. (2019). Analisis Efektivitas Implementasi Peraturan Pemerintah No 23 Tahun 2018 Tentang Pajak Penghasilan Untuk Pelaku Usaha Mikro, Kecil Dan Menengah (Umkm) (Studi Kasus Pada Pelaku Umkm Di Pujasera Bapak Raden Tahun 2019). Journal of Chemical Information and Modeling, 53(9), 16891699. https://doi.org/10.1017/CBO9781107415324.004

Mutiah, M., Harwida, G. A., \& Kurniawan, F. A. (2011). Interpretasi Pajak dan Implikasinya menurut Perspektif Wajib Pajak Usaha Mikro, Kecil, dan Menengah. Jurnal Akuntansi Multiparadigma, 2, 418. https://doi.org/10.18202/jamal.2011.12.7129

Prabantari, F., \& Ardiyanto, M. (2017). Implementasi Pajak Penghasilan Berdasarkan Peraturan Pemerintah Nomor 46 Tahun 2013 (Studi Pada UMKM Di Jawa Tengah Dan Daerah Istimewa Yogyakarta). 6(4), 399-410.

Raco, J. (2018). Metode penelitian kualitatif: jenis, karakteristik dan keunggulannya (Arita L, Ed.). https://doi.org/10.31219/osf.io/mfzuj 
Suari, E. V., \& Rasmini, N. K. (2018). Pemahaman Peraturan, Efektivitas Sistem, Kewajiban Moral, Kualitas Pelayanan, Sanksi Perpajakan Pada Kemauan Ikut Tax Amnesty. E-Jurnal Akuntansi, 22, 108. https:// doi.org/10.24843/EJA.2018.v22.i01.p05

Suci, T. S. M., Karamoy, H., \& Rondonuwu, S. (2019). Efektivitas Penerapan Peraturan Pemerintah No.23 Tahun 2018 Terhadap Tingkat Pertumbuhan Wajib Pajak Dan Penerimaan Pph Final Pada Kpp Pratama Manado. Going Concern: Jurnal Riset Akuntansi, 14(4), 362-370. https://doi.org/10.32400/gc.14.4.26289.2019

Sugiyono. (2016). Metode Penelitian Kuantitatif, Kualitatif dan RED. Bandung: Alfabeta.

Susilo, E. J., \& Sirajuddin, B. (2014). Pemahaman Wajib Pajak Terhadap Peraturan Pemerintah Nomor 46 Tahun 2013 Tentang Pajak UKM (Studi Kasus Pada Wajib Pajak yang Terdaftar di Kantor Pelayanan Pajak Pratama Palembang Ilir Barat). Jurnal Akuntansi, (46), 1-10.

Sutono, \& Ardi, B. K. (2018). Peran Penting Peraturan Pemerintah (PP) RI Nomor 46 Tahun 2013 Terhadap Kepatuhan Wajib Pajak. (45), 69-78.

Syafiqurrahman, M., Budiatmanto, A., Widjajanto, A., Wibawa, A., Setyawan, D., \& Anwar, R. A. (2017). Analisis Pengaruh PP 46 Tahun 2013 terhadap Upaya Pemerintah dalam Meningkatkan Perekonomian Indonesia Melalui Sektor UMKM. Journal of Applied Accounting and Taxation, 2(2), 75-82. Retrieved from https://zenodo.org/record/1306085\#.XKnKX_kzbIU

Wahyuni, I. (2017). Identifikasi Kebutuhan Penggunaan Laporan Keuangan Pada Pelaku UMKM.

Wardani, D. K., \& Wati, E. (2018). Pengaruh Sosialisasi Perpajakan Terhadap Kepatuhan Wajib Pajak Dengan Pengetahuan Perpajakan Sebagai Variabel Intervening (Studi Pada Wajib Pajak Orang Pribadi Di Kpp Pratama Kebumen). Nominal, Barometer Riset Akuntansi Dan Manajemen, 7(1). https://doi.org/10.21831/nominal.v7i1.19358 